\title{
TIMBER PRODUCTION MARKET IN POLAND AND SELECTED EU COUNTRIES - CURRENT STATUS AND FUTURE CHALLANGES
}

\author{
Pawet GAJDEMSKI, Ewelina GAWEt, Krzysztof GARDZIEJ, \\ Bartosz KLUCZYŃSKI, Mateusz ORŁOWSKI \\ University of Zielona Góra \\ Kahreena HORTIZUELA \\ Azusa Pacific University
}

\begin{abstract}
:
The paper discusses the issue of the development of timber production market and timber industry in Poland and selected EU countries. The potential of forest resources in Poland against the background of other European countries is presented, as well as selected aspects exerting impact on the development processes of the sector of production. Particular attention is paid to the structure of ownership of forests in Poland and selected countries of the European Union. The structure of the use of means for research and development is analyzed with particular focus on those branches which allocate the biggest amounts for such purposes. Technological trends in the timber industry in Poland is described. Finally the prospects in the development of timber industry in the near future are discussed.
\end{abstract}

Key words: wood, timber industry, timber production, forest resources

\section{INTRODUCTION}

Most people associate forest with a quiet place, ideal for a Sunday walk. Even in the times of plastic, raw materials obtained from forest areas constitute a significant element in numerous branches of economy. This can be illustrated by massive logging in the South America, Asia or Africa. Lack of balance in this kind of activity leads to the decrease of forest areas. This shows that the global demand for wood is very high, and despite passage of time, timber industry is still thriving. The paper discusses the problem of the development of the timber production market in Poland and several countries of the European Union, in order to present its current status and future development prospects.

\section{FOREST RESOURCES AND TIMBER PRODUCTION IN PO- LAND AND IN THE WORLD}

In the era of metal, glass and plastic, it might seem that is wood no longer a useful raw material. However it turns out, that this is far from true, since it still used for a large scale. "It is estimated, that at present wood has approximately 30 thousand application: both wood as well as wood based materials are used among others in construction industry, mining, energy production, production of agricultural machines, floors, furniture, boards, paper, packaging, tools, music instruments, sports equipment, toys or office materials" [9].

As far as forest resources are concerned, Poland occupies a high position among the manufactures of wooden products in Europe. Major part of the production of the Polish timber industry is exported. At the beginning of the $21^{\text {st }}$ century, a real revolution took place in the foresttimber sector, which changed the balance between produc- tion and demand for timber. The changes affected also Polish producers, which can be illustrated by the development in mechanization of forestry [6].

According to the data Food and Agriculture Organization of the United Nations, in 2001 forest areas constituted $31 \%$ of the surface of the Earth, which totaled at 4 billion ha. In 2009, 3.29 billion $\mathrm{m}^{3}$ of wood was aquired in the Word, out of which almost have was used as fuel. In developing countries of Asia and Africa, firewood constituted approximately $80 \%$ of the total production, whereas in Europe it slightly more than $20 \%$ [7].

According to the data of the Central Statistical Office, in 2014 in Poland forest areas covered 9403 thousand ha, which is $30 \%$ of the area of the country. Poland is one of the leading wood producers in the world. "State Forests which cover more than $90 \%$ of the demand for wood in Poland remain the major supplier. On the average more than half of log volume which grows in the forest is acquired - the remaining part increases the stock. That is why the resources of wood in State Forests increase - over the last 20 years by almost 500 million $\mathrm{m} 3$ of large timber gross" [11].

The company State Forests logs more than 35 million $\mathrm{m}^{3}$ of timber a year. The highest percentage of the raw material, approximately $80 \%$, is designated for wholesale for manufacturers specializing in timber, paper or furniture production, out of which:

- most of the material is sold through the Internet on the special Forest - Timber website,

- a significant part is sold to companies specializing in increasing productive capacity (which supports their development), 
- the remaining part of the material, which in not bought through the website, is sold at online auctions.

Individual receivers, who buy firewood, are also among the customers of the State Forests. A limited percentage of timber, classified as wood of unique quality, is sold at online auctions. The remaining part (approximately 1\%) is used for specific purposes of the State Forests, such as construction of the infrastructure [11].

\section{FOREST RESOURCES AND THE TIMBER PRODUCTION MARKET IN SELECTED COUNTRIES OF THE EUROPEAN UNION}

Finland is certainly one of the leaders on the timber market in the European Union. A significant percentage of the area of the country (as much as 70\%) is covered by forest. In comparison, in Poland forest covers $30 \%$ of the area of the country. Timber market in Finland constitutes a significant element stimulating the growth of the economy of this country. Pulp and paper production industry is particularly strong and remains one of the major consumers of timber. Forests in Finland have a specific structure of ownership. In contrast to Poland (where most forest areas are owned by the state), in Finland $60 \%$ of the forest areas is private - state owned forest are mainly national parks or natural reserves. Despite significant amount of wood in Finland, the country put a particular stress on importing timber from such countries as Russia, Latvia or Estonia. Products of the forest sector constitute $20 \%$ of the export of the country mainly to France, the USA, Germany or Great Britain [4]

Similarly in Sweden, private forest areas prevail (approximately 80\%). Almost 63 thousand companies, employing approximately 2.4 million workers, i.e. $26 \%$ of the population, operate in the forest industry. "Sweden is the fourth supplier of paper in the world, the third exporter of the wood pulp and the second supplier of sawn wood. One workplace in the Swedish forest industry sector crates two workplaces at in such sectors as machine, construction, transport or IT industry" [5].

\section{SELECTED ASPECTS OF THE DEVELOPMENT OF THE POLISH TIMBER PRODUCTION MARKET}

Just like in other countries, the development of the timber sector in Poland faces several problems, and in particular the increasing supply of wood on the market. The consideration of social questions constitutes another challenge facing Polish timber market. There is a need to change the way in which the forms of acquiring wood is perceived by the society, that is as forest devastation. Undoubtedly the principle of sustainable development, followed by the timber industry, must be made Real. Three purposes must be combined: economic, social and environmental, that protection of resources. The Protection of forest resources is possible thanks to, among others, multiple recycling, use of after utility wood and introduction of materials and energy saving technologies, developed in Poland, or the option of importing both after utility wood and such technologies form our western neighbors - Germany or Scandinavian countries [10].

The concept of "introduction of technologies" on the Polish timber market was mentioned above. Undoubtedly introduction of a new technology is connected with the need of research. All beneficial technologies and the latest know-how should be commercialized, which automatically means high expenditure. The aim of the commercialization, mentioned above, is to generate profit in the future, both from the introduction of new technologies and innovative products. In recent years, in the Polish timber sector, an increase of the expenditure on innovation can be observed, yet its scale is still unsatisfactory. In 2012 the expenditure on innovation amounted at 1.2 billion PLN, in comparison in 2010 totaled at 960 million PLN. The highest expenditure on innovation in 2012 was observed in furniture manufacturing $-49 \%$ of the expenditure in the entire sector, and pulp and paper production industry - $39 \%$ of the total expenditure. For the sake of comparison, the remaining $12 \%$ were allocated to the timber industry [2].

The highest percentage of the investment in the timber sector is spent on machines and facilities, almost $73 \%$ in 2012. In turn, in the timber industry, the percentage amounted at $69 \%$, furniture manufacturing - $65 \%$ and as much $83 \%$ in the pulp and paper production industry. The fact that in 2012 only $5.5 \%$ of the expenditure was allocated for research and development does instill optimism [2].

Technological trends in the timber sector have changed significantly over the recent years. The tendency to replace traditional wooden materials by refined wooden products, constitutes an example of such trends. Another trends is to replace wooden materials by plastic. One of the innovative solutions introduced by companies consists in the form and technology of varnishing which eliminated harmful chemical substances. Methods of protecting wood from excessive humidity and increasing its resistance to fungi and external factors by thermal processing are also used. The thermal process is currently the most developed form of wood modification [1].

On the international arena, Polish timber industry can be characterized by limited use of wooden products. This is caused by a lower level of the technological advancement of Polish producers. In Poland, the manufacturing process of wooden products, starting from the processing of the raw material and ending on the final product, is quite often performed in one factory. In western plants, a tendency to assemble semi-finished products can be observed. This is caused by the use of services provided by subcontractors, which translates negatively into the level of efficiency of the production of Polish furniture in comparison to Europeans furniture. The problem seems to have been already noticed in Poland. Polish entrepreneurs increasing more often modernize the production process of materials and products [1].

As far as the technological advancement of the facilities are concerned, the manufactures of cellulose, paper and wood based boards dominate. The first position of the these two producers is caused by the fact that the technological process of the production of boards is continuous amd the production lines require constant modernization [8].

In 2015 the Polish timber sector witnessed the opening of the third in the world and the first in Poland, LVL (laminated veneer lumber) factory. This is a modern material used mainly for construction purposes. It is characterized by high mechanical strength, low weight, high quality and resistance. The production technology used in the STEICO factory in Czarna Woda is one of the most modern technologies in the world. It was provided by the Finnish company Raute which the world leader in technologies of LVL production. 


\section{CONCLUSIONS}

The conclusions concerning timber production market in Poland are of particular interest. The forestation rate in Poland approximates $30 \%$, which is close to the world average (31\%). The investment expenditure borne by the timber industry is allocated mainly for new machines and facilities used in the production process. Only a small fraction of the investment expenditure is allocated for innovation, it has to be noticed however, increasingly more is spent on research and development. Cellulose and paper production industry is most advanced technologically. The major problem of the producers from this branch consists in the monopolistic position of the company State Forests. Lack of competition results in high price and limited supply of wood on the Polish market.

The analysis of the European leaders in wood production indicated at a certain geographical aspect. Sweden and Finland, countries located on the Scandinavian peninsula are at the top. The may be caused by the fact that most forest areas in these countries are privately owned, and hence administrative or bureaucratic intervention is limited. In Sweden alone $1 / 4^{\text {th }}$ of all employees works in the timber industry.

Nothing indicates that the sector of wood production could face a crisis in the near future. Trees constitute one of the renewable raw materials, which can be acquired from the environment, yet the process of cultivation is relatively long. While bearing in mind the principles of sustainable development, we are able to take care of both the natural environment as well as profits of entrepreneurs.

\section{REFERENCES}

[1] Analiza trendów rozwojowych w zakresie technologii i nowych myśli technicznych w Polsce, Europie i świecie dla branży drzewno-meblarskiej. Projekt „Transfer wiedzy w regionie poprzez rozwój sieci współpracy", realizowany w ramach Priorytetu VIII Regionalne kadry gospodarki, Działania 8.2 Transfer wiedzy, Poddziałania 8.2.2 Regionalne strategie innowacji Programu Operacyjnego Kapitał Ludzki współfinansowanego z Europejskiego Funduszu Społecznego. [Online]. http://www.rsi.org.pl/
[2] M. Grabowski, Poland statement on the wood market review and prospects. [Online]. https:// www.unece.org/

[3] D. Jabłoński, STEICO LVL: nowoczesna technologia w przemyśle drzewnym. [Online]. http:// www.drewno.pl/

[4] P. Kierasiński, (2014). Finlandia przemysł drzewny i meblarski. [Online]. http://4woodi.pl/

[5] P. Kierasiński, Szwecja - rynek drzewny. [Online]. http://4woodi.pl/

[6] J. Kruk, Polski sektor drzewny w warunkach zmian na rynkach międzynarodowych [Online]. http:// www.itd.poznan.pl/

[7] T, Moskalik, W. Nowacka, J. Sadowski, D. Zastocki, Rynek drewna energetycznego w Polsce jako element rozwoju regionalnego. Lasy dla ludzi, ludzie dla lasów. Centrum Edukacji Przyrodniczo-Leśnej R. 14. Zeszyt 32/3/2012. Rogów. 2012. pp. 222-230.

[8] E. Ratajczak, Innowacyjność sektora drzewnego w Polsce, Instytut Technologii Drewna. Poznań. 2009. pp. 93.

[9] Ł. Sawa, Surowiec do wszystkiego. [Online]. http:// www.sycow.poznan.lasy.gov.pl/

[10] W. Strykowski, Dokqd zmierza polski sektor leśnodrzewny w warunkach rozwoju gospodarki. [Online]. http://www.itd.poznan.pl/

[11] K. Trębski, [Online]. http://www.lasy.gov.pl/

\author{
Paweł Gajdemski, Ewelina Gaweł, Krzysztof Gardziej, \\ Bartosz Kluczyński, Mateusz Orłowski \\ University of Zielona Góra \\ "Eco-Management" Student Research Club \\ ul. Licealna 9, 65-417 Zielona Góra, POLAND \\ e-mail: pawpixel@gmail.com, e.gawel@onet.pl, \\ krzysiek.gardziej@wp.pl, bartoszkluczynski1@gmail.com, \\ mateusz_93@vp.pl, \\ Kahreena Hortizuela \\ Azusa Pacific University, USA \\ e-mail: Ipham12@apu.edu
}

Artykuł w polskiej wersji językowej dostępny na stronie internetowej czasopisma.
The article in Polish language version available on the website of the journal 